\title{
Faktor Mathematical Habits Of Mind dan Kemampuan Literasi Matematis Siswa SMP di Kabupaten Bandung Barat
}

\author{
The Factor Of Mathematical Habits of Mind and Mathematics Literacy Students Ability \\ Of Junior High School \\ In West Bandung Regency
}

\author{
Putri Eka Indah Nuurjannah ${ }^{1}$ *, Heris Hendriana ${ }^{2}$, Aflich Yusnita Fitrianna ${ }^{3}$ \\ ${ }^{123}$ Program Studi Pendidikan Matematika, IKIP Siliwangi Bandung. Jalan Terusan Jenderal \\ Sudirman Cimahi, 40526 \\ * Korespondensi Penulis. E-mail: putrimuhid@gmail.com, Telp: +6281224741990
}

Keywords:

Mathematical habits of mind Kemampuan literasi matematis Korelasi

\begin{abstract}
Abstrak
Matematika terbentuk sebagai pemikiran manusia yang berhubungan dengan ide, proses, dan penalaran. Manusia hidup selalu berdampingan dengan masalah yang kompleks dan perlu adanya sikap kritis dalam menghadapinya dan mampu memprediksi suatu kejadian yang terjadi, serta mampu menyelesaikan masalah tersebut dengan penalarannya yang baik. Oleh karena itu, sangat diperlukan kemampuan literasi matematis pada diri setiap siswa. Selain kemampuan kognitif yang harus dikembangkan, tetapi juga kemampuan afektif harus dimiliki oleh setiap siswa. Terdapat hubungan yang positif antara sikap dengan prestasi matematika, salah satunya dengan mathematical habits of mind. Tujuan penelitian ini untuk mendeskripsikan hubungan mathematical habits of mind terhadap kemampuan literasi matematis siswa SMP di Kabupaten Bandung Barat. Penelitian ini menggunakan pendekatan kuantitatif dengan analisis data korelasi. Penelitian ini dilakukan di SMP di Kabupaten Bandung Barat. Subjek pada penelitian ini sebanyak 37 siswa kelas IX yang dipilih dengan teknik purposive sampling. Hasil penelitian menunjukkan bahwa perolehan nilai korelasi $r_{s}>r_{s}$-table sebesar 0,631 $>0,325$, nilai $t$-test $>t$-table sebesar 4,81 $>1,69$, dan koefisien determinasi sebesar 39,8\%. Dapat diambil kesimpulan bahwa adanya hubungan yang signifikan antara mathematical habits of mind terhadap kemampuan literasi matematis siswa SMP di Kabupaten Bandung Barat, dengan pengaruh mathematical habits of mind terhadap kemampuan literasi matematis siswa sebesar 39,8 \% dan sisanya dipengaruhi oleh faktor lain yang tidak diukur dalam penelitian ini. Memiliki mathematical habits of mind yang tinggi dalam diri siswa, akan memberikan peningkatan kemampuan literasi matematis yang baik.
\end{abstract}


Vol. 2, No. 2, April 2018, pp. 51-58

\begin{abstract}
Mathematics is formed as human thinking associated with ideas, processing, and reasoning. Human life is always coexists with complex problems and needs a critical attitude in dealing with it and able to predict an event that happened, and able to solve the problem with good reasoning. Therefore, it is necessary the ability of mathematics literacy. In addition to the cognitive abilities that must be developed, but also the affective ability must be owned by the students. There is a positive correlation between attitudes with mathematical achievement, one with mathematical habits of mind. This study aims to describe the correlation between mathematical habits of mind and mathematics literacy students ability of junior high school in West Bandung Regency. This study is a quantitative research with correlation analyze. This study was conducted of junior high school in West Bandung Regency. The research respondens were studied consist of 37 students of junior high school grade IX in West Bandung Regency. The study was used purposive sampling. The result showed that the value of correlation $r_{s}>r_{s}$-table of $0,631>0,325$, the value of t-test $>t$-table of $4,81>$ 1,69 , and coefficient of determination of $39,8 \%$. It can be concluded that there is a significant correlation between mathematical habits of mind to the mathematics literacy students ability of junior high school in West Bandung Regency, with the influence of mathematical habits of mind to mathematics literacy students ability of 39,8\% and therest influenced by other factors not measured in this study. Has a high mathematical habits of mind in students, will provide improved the mathematics literacy ability.
\end{abstract}

Copyright (C) 2017 Universitas Mercu Buana Yogyakarta. All rights reserved.

\title{
PENDAHULUAN
}

Matematika terbentuk sebagai pemikiran manusia yang berhubungan dengan ide, proses, dan penalaran (Ruseffendi, 1980). Matematika ialah salah satu mata pelajaran yang dipelajari di setiap jenjang pendidikan, baik dari jenjang sekolah dasar, sekolah menengah, hingga perguruan tinggi. Tujuan matematika sekolah, baik formal maupun material yakni menekankan kepada menata penalaran dan membentuk kepribadian siswa, dan menekankan kepada kemampuan memecahkan masalah dan menerapkan matematika (Ekawati, 2011).

Tujuan tersebut tak lepas dari arti matematika itu sendiri, dan mendukung ketercapaian tujuan pendidikan nasional dalam undang-undang nomor 20 tahun 2003, yaitu: "Pendidikan nasional berfungsi mengembangkan kemampuan dan membentuk watak serta peradaban bangsa yang bermartabat dalam rangka mencerdaskan kehidupan bangsa, bertujuan untuk berkembangnya potensi peserta didik agar menjadi manusia yang beriman dan bertakwa kepada Tuhan Yang Maha Esa, berakhlak mulia, sehat, berilmu, cakap, kreatif, mandiri, dan menjadi warga negara yang demokratis serta bertanggungjawab."

Secara sadar ataupun tidak sadar, manusia hidup selalu berdampingan dengan masalah yang kompleks dan perlu adanya sikap kritis dalam menghadapinya dan mampu memprediksi suatu kejadian yang terjadi, serta mampu menyelesaikan masalah tersebut dengan penalarannya yang baik. Oleh karena itu, sangat diperlukan kemampuan literasi matematis. Literasi matematis didefiniskan menurut draft assessment PISA 2015: "mathematical literacy is an individual"s capacity to formulate, employ, and interpret in a variety of contexts. It includes reasoning mathematically and using mathematical concepts, procedures, facts and tools to describe, explain and predict phenomena. It assist individuals to recognise the role that mathematics plays in the world and to make well-founded judgements and decisions needed by constructive, enganged, and reflective citizens." (OECD, 2017). 
Dijelaskan bahwa literasi matematis merupakan kemampuan individu untuk merumuskan, menerapkan, dan menafsirkan matematika dalam berbagai konteks. Termasuk didalamnya meliputi penalaran matematis dan penggunaan konsep, prosedur, fakta, dan alat matematika untuk mendeskripsiskan, menjelaskan, dan memperkirakan suatu fenomena atau kejadian. Hal ini membantu individu mengenali peranan matematika dalam kehidupan dan membuat penilaian yang baik maupun pengambilan keputusan yang dibutuhkan warga negara yang konstruktif dan reflektif.

Kemampuan literasi matematis diteliti oleh organisasi survei internasional PISA (Programme for International Student Assesmnet) yang diselenggarakan oleh OECD (Organisation for Economic Co-operartion and Development) setiap tiga tahun sekali kepada siswa berusia 15 tahun. Indonesia mulai berpartispasi sejak tahun 2000 , kemudian mengikuti ditahun berikutnya yaitu pada tahun 2003, 2006, 2009, 2012, dan sampai baru ini di tahun 2015. Hasil yang diperoleh anak-anak Indonesia pada tahun terbaru ini masih rendah, walaupun ada sedikit peningkatan dari tahun sebelumnya. Rerata skor literasi matematis tahun 2015 yaitu 386 (level 2), sedangkan rerata skor internasional sebesar 496 pada level 3("Peringkat dan Capaian PISA Indonesia Mengalami Peningkatan," 2016). Pada tahun 2012 dan 2009 berturut-turut hanya mencapai 375 dan 371.

Dari hasil survei tersebut, mengindikasikan bahwa rerata siswa Indonesia baru mampu menduduki level 1 dan level 2, sedangkan level 3 dan level 4 belum tercapai. Sehingga peneliti menentukan level kemampuan literasi matematis pada level 3 dan level 4 sebagai pembatasan penelitian yang dilakukan terhadap variabel terikat.

Menurut Setiana (2016), terdapat faktor intern yang dapat mempengaruhi siswa belajar yakni tingkat kecerdasan (intelektual), perhatian, minat, bakat, motivasi, kematangan, dan kesiapan. Menurut Umar (Miliyawati, 2014), menyatakan bahwa selain kemampuan kognitif yang harus dikembangkan, tetapi juga kemampuan afektif harus dimiliki oleh setiap siswa. Menurut Mullis, terdapat hubungan yang positif antara sikap dengan prestasi matematika (Miliyawati, 2014).

Dari pendapat tersebut, salah satu kemampuan afektif yang harus dimiliki dan ditingkatkan pada diri setiap siswa ialah MHM (Mathematical Habits of Mind) atau kebiasaan berpikir matematis. Mathematical habits of mind didefinisikan menurut Cuoco (Andriani, Yulianti, Ferdias, \& Fatonah, 2017) bahwa sebagai kebiasaan berpikir yang dilakukan oleh matematikawan dalam memikirkan konsep dan masalah matematis. Dalam kutipannya menyatakan: "Mathematical habits of mind can motivate the students to make connection between mathematics ideas". Dijelaskan bahwa mathematical habits of mind dapat memotivasi siswa untuk membuat hubungan atau keterkaitan antara gagasan-gagasan matematika.

Mathematical habits of mind terbentuk dari banyak keterampilan, sikap, pengalaman, dan kecenderungan. Costa mengidentifikasi enam belas kebiasaan berpikir (Hendriana, Rohaeti, \& Sumarmo, 2017) sebagai berikut: (1) bertahan atau pantang menyerah; (2) mengatur kata hati; (3) mendengarkan pendapat orang lain dengan rasa empati; (4) berpikir luwes; (5) berpikir metakognitif; (6) berusaha bekerja teliti dan tepat; (7) bertanya dan mengajukan masalah secara efektif; (8) memanfaatkan pengalaman lama untuk membentuk pengetahuan baru; (9) berpikir dan berkomunikasi secara jelas dan tepat; (10) memanfaatkan indera dalam mengumpulkan dan mengolah data: (11) mencipta, berkhayal, dan berinovasi; (12) bersemangat dalam merespons; (13) berani bertanggungjawab dan menghadapi resiko; (14) humoris; (15) berpikir saling bergantungan; dan (16) belajar berkelanjutan.

Dalam konteks matematika, Millman dan Jacobe mengidentifikasi beberapa indikator mathematical habits of mind (Hendriana dkk., 2017), diantaranya: (1) mengeksplorasi ide-ide matematis; (2) merefleksi kebenaran jawaban masalah matematis; (3) mengidentifikasi strategi pemecahan masalah yang dapat diterapkan untuk menyelesaikan masalah dalam skala lebih luas; (4) bertanya pada diri sendiri apakah terdapat "sesuatu yang lebih" dari aktivitas matematika yang telah dilakukan (generalisasi); (5) memformulasi pertanyaan matematis; dan (6) mengonstruksi contoh matematis.

Untuk mengukur mathematical habits of mind siswa diperlukan beberapa indikator, pada penelitian ini indikator yang digunakan berdasarkan indikator menurut Costa dan Millman (Hendriana dkk., 2017) adalah sebagai berikut: (1) mengeksplorasi ide-ide matematis; (2) 
Vol. 2, No. 2, April 2018, pp. 51-58

mengidentifikasi strategi pemecahan masalah yang dapat diterapkan untuk menyelesaikan masalah dalam skala lebih luas; (3) bertanya pada diri sendiri apakah terdapat "sesuatu yang lebih" dari aktivitas matematika yang telah dilakukan (generalisasi); (4) bertahan atau pantang menyerah; (5) berpikir luwes; (6) bertanya dan mengajukan masalah secara efektif; (7) mendengarkan pendapat orang lain dengan rasa empati; (8) memanfaatkan pengalaman lama untuk membentuk pengetahuan baru; dan (9) belajar berkelanjutan.

Berdasarkan penjelasan di atas, penelitian ini bertujuan untuk mendeskripsikan faktor mathematical habits of mind dan kemampuan literasi matematis siswa SMP di Kabupaten Bandung Barat.

\section{METODE}

Penelitian ini menggunakan pendekatan kuantitatif dengan analisis data korelasi. Penelitian dilakukan di SMP di Kabupaten Bandung Barat. Subjek pada penelitian ini sebanyak 37 siswa kelas IX yang dipilih dengan teknik purposive sampling.

Instrumen yang digunakan dalam penelitian ini yaitu tes untuk mengukur kemampuan literasi matematis siswa dan kuisioner atau angket untuk mengukur tingkat mathematical habits of mind. Kuisioner mathematical habits of mind diadopsi dari penelitian yang pernah dilakukan oleh Zakiah (2014). Skala mathematical habits of mind tersebut dijawab dengan mengacu pada skala Likert. Siswa diminta untuk menjawab setiap pernyataan ataupun pertanyaan dengan memberi tanda checklist pada satu jawaban yang telah tersedia. Pemberian skor pada tiap pilihan jawaban berpedoman pada skala Likert dengan empat pilihan jawaban, berupa "sangat tidak setuju", "tidak setuju", "setuju", dan "sangat setuju". Sedangkan tes kemampuan literasi matematis yang digunakan adalah level 3 yang terdiri dari 2 butir soal dan level 4 yang terdiri dari 3 butir soal. Soal tes berbentuk uraian dengan materi lingkaran. Tes kemampuan literasi matematis telah melalui uji keabsahan dengan uji validitas dan reliabel baik.

Uji prasyarat analisis data dalam penelitian ini, dengan uji normalitas. Uji normalitas dilakukan untuk mengetahui apakah sampel data diambil dari populasi berdistribusi normal atai tidak normal. Statistik uji normalitas yang digunakan adalah Kolmogorov Smirnov dengan bantuan software SPSS versi 21. Dalam penelitian ini, uji normalitas dilakukan berdasarkan variabel mathematical habits of mind dan kemampuan literasi matematis siswa. Hipotesis untuk uji normalitas ialah penerimaan $\mathrm{H}_{0}$ atau penolakan $\mathrm{H}_{a}$ dengan $\mathrm{H}_{0}$ : Data berdistribusi normal dan $\mathrm{H}_{a}$ : Data tidak berdistribusi normal. Hasil uji normalitas disajikan pada Tabel 1 sebagai berikut.

Tabel 1. Data Hasil Uji Normalitas

\begin{tabular}{ccc}
\hline & $\begin{array}{c}\text { Mathematical } \\
\text { Habits of Mind }\end{array}$ & $\begin{array}{c}\text { Kemampuan } \\
\text { Literasi } \\
\text { Matematis }\end{array}$ \\
\hline $\begin{array}{c}\text { Signifikansi }(\alpha=\mathbf{0 , 0 5}) \\
\text { Keputusan Uji } \\
\text { Keterangan }\end{array}$ & 0,001 & 0,006 \\
$\mathrm{H}_{a}$ & $\mathrm{H}_{a}$ \\
\hline
\end{tabular}

Dari Tabel 1, terlihat bahwa signifikansi dari kedua variabel kurang dari 0,05 yang berarti tidak adanya penolakkan keputusan uji $\mathrm{H}_{a}$ atau dengan kata lain adanya penolakkan $\mathrm{H}_{0}$. Dengan ini, untuk setiap sampel variabel mathematical habits of mind maupun kemampuan literasi matematis berasal dari populasi yang tidak berdistribusi normal.

Teknik analisis data yang digunakan pada penelitian ini adalah analisis korelasi. Analisis korelasi digunakan untuk memperoleh deskripsi dari hubungan antara mathematical habits of mind dengan kemampuan literasi matematis siswa. Berdasar hasil uji normalitas tersebut, untuk menentukan koefisien korelasi pada penelitian ini dilakukan dengan menggunakan korelasi Rank Spearman menurut Sugiyono (2011) sebagai berikut. 


$$
r_{\Omega}=\frac{\sum X^{2}+\sum Y^{2}-\sum d i^{2}}{2 \sqrt{\sum X^{2} \sum Y^{2}}}
$$

Setelah diperoleh adanya hubungan antara variabel $\mathrm{X}$ terhadap variabel $\mathrm{Y}$, ditentukan tingkat hubungan antar variabel tersebut berdasarkan interpretasi koefisien korelasi yang disajikan pada Tabel 2 menurut Sugiyono (Darma, Firdaus, \& Haryadi, 2016).

\section{Tabel 2. Interpretasi Koefisien Korelasi}

\begin{tabular}{cc}
\hline Interval Koefisien & Tingkat Hubungan \\
\hline $0,00-0,199$ & Sangat rendah \\
$0,20-0,399$ & Rendah \\
$0,40-0,599$ & Sedang \\
$0,60-0,799$ & Kuat \\
$0,80-1,000$ & Sangat kuat \\
\hline
\end{tabular}

Selanjutnya, ditentukan nilai signifikansi dari hubungan antara variabel $\mathrm{X}$ terhadap variabel $\mathrm{Y}$ dengan menggunakan $t$-test sebagai berikut:

$$
t=r_{s} \sqrt{\frac{n-2}{1-r_{s}^{2}}}
$$

Untuk menentukan besar pengaruh antar variabel atau kontribusi variabel mathematical habits of mind terhadap kemampuan literasi matematis siswa, ditentukan koefisien determinasi menurut Sugiyono (Hutagalung, 2016) sebagai berikut:

$$
K D=r_{s}^{2} \times 100 \%
$$

Langkah-langkah yang dilakukan dalam menganalisis data pada penelitian ini, yaitu mengumpulkan dan mengolah semua data yang diperoleh selama di lapangan, dengan memeriksa dan menganalisis hasil tes berdasarkan indikator-indikator yang ditentukan dan hasil kuisioner mathematical habits of mind (sangat tidak setuju, tidak setuju, setuju, dan sangat setuju). Kemudian menganilisis tingkat hubungan antara mathematical habits of mind terhadap kemampuan literasi matematis, dengan melihat nilai $r_{\varepsilon}$ yang dibandingkan dengan $r_{s}$-table, dan dilanjutkan menentukan tingkat hubungannya berdasar interpretasi yang telah disajikan. Selanjutnya menentukan $t$-test sebagai uji signifikansi hubungan antar variabel juga dibandingkan dengan $t$ table, kemudian menentukan nilai koefisien determinasi.

\section{HASIL DAN PEMBAHASAN}

Uji korelasi dilakukan dengan menggunakan korelasi Rank Spearman. Hipotesis untuk uji korelasi ialah penolakkan $\mathbf{H}_{0}$ atau penerimaan terhadap $\mathrm{H}_{a}$, dengan $\mathrm{H}_{0}$ : Tidak terdapat hubungan antara mathematical habits of mind terhadap kemampuan literasi matematis siswa SMP, dan $\mathrm{H}_{\alpha}$ : Terdapat hubungan antara mathematical habits of mind terhadap kemampuan literasi matematis siswa SMP. Hasil uji disajikan pada Tabel 3 sebagai berikut.

Tabel 3. Rekapitulasi Uji korelasi Rank Spearman

\begin{tabular}{ccc}
\hline Mathematical & $\begin{array}{c}\text { Kemampuan } \\
\text { Habits of Mind }\end{array}$ & $\begin{array}{c}\text { Matematis } \\
\text { Matematis }\end{array}$ \\
\hline $\boldsymbol{n}$ & 37 & 37 \\
$\overline{\mathbf{X}}$ & 77,51 & 26,32 \\
Mo & 75 & 30 \\
Me & 78 & 28 \\
Min & 54 & 12
\end{tabular}


Vol. 2, No. 2, April 2018, pp. 51-58

\begin{tabular}{ccc}
\hline & $\begin{array}{c}\text { Mathematical } \\
\text { Habits of Mind }\end{array}$ & $\begin{array}{c}\text { Kemampuan } \\
\text { Literasi } \\
\text { Matematis }\end{array}$ \\
\hline Maks & 86 & 34 \\
SD & 5,630 & 4,928 \\
Correlation $\left(r_{S}\right)$ & & 0,631 \\
\hline
\end{tabular}

Berdasarkan rekapitulasi hasil perhitungan korelasi Rank Spearman, diperoleh $r_{s}=0,631$. Selanjutnya untuk mengetahui ada atau tidaknya hubungan antara variabel mathematical habits of mind terhadap kemampuan literasi matematis, akan dibandingkan dengan nilai $r_{\varepsilon}$-table yang menggunakan taraf signifikansi $5 \%$. Dari data $r_{g}$-table dengan $n=37$ dan $\alpha=0,05$, diperoleh nilai $r_{s}$-table $=0,325$. Berdasarkan data tersebut, $r_{s}>r_{s}$-table, maka $\mathbf{H}_{0}$ ditolak atau $0,631>0,325$ dan perolehan nilai korelasi Rank Spearman termasuk dalam interval $0,60-0,799$ dengan kategori kuat, sehingga dapat disimpulkan bahwa terdapat hubungan yang kuat antara mathematical habits of mind terhadap kemampuan literasi matematis siswa SMP. Hal ini sesuai dengan pendapat Mullis bahwa terdapat hubungan yang positif antara sikap dengan prestasi matematika (Miliyawati, 2014).

Selanjutnya, diperoleh $t$-test $=4,81$. Untuk menentukan signifikan atau tidaknya hubungan antara mathematical habits of mind terhadap kemampuan literasi matematis siswa SMP, kemudian t-test dibandingkan dengan $t$-table yang menggunakan taraf signifikansi $5 \%$. Dari data $t$-table dengan $d f=n-2=35$ dan $\alpha=0,05$, diperoleh nilai $t$-table $=1,69$. Berdasarkan data tersebut, t-test $>$ t-table atau 4,81>1,69, maka $\mathrm{H}_{0}$ ditolak. Dapat disimpulkan bahwa terdapat hubungan yang signifikan antara mathematical habits of mind terhadap kemampuan literasi matematis siswa SMP.

Hal ini bersesuaian dengan indikator kuisioner yang digunakan menurut Costa dan Millman (Hendriana dkk., 2017) sebagai contoh yakni mengeksplorasi ide-ide matematis. Jika siswa dapat mengeksplorasi ide-ide matematisnya, maka siswa tersebut akan membuat rincian selesaian berupa mengidentifikasi data dan mampu berinteraksi dengan orang lain, kemudian berusaha dengan sungguh-sungguh untuk menyelesaikan masalah dengan baik. Siswa yang memiliki mathematical habits of mind akan memiliki pandangan bahwa tugas-tugas yang sulit sebagai suatu tantangan untuk mampu menyelesaikan masalah dalam kehidupan nyata yang kompleks dengan sikap tangguh, ulet, dan percaya diri. Selain itu, siswa juga selalu menetapkan komitmen dalam setiap tugas yang dikerjakannya untuk selalu belajar, mengevaluasi, dan berusaha menjadi lebih baik. Hal tersebut, tentu akan memberikan peningkatan kemampuan literasi matematis yang baik, jika siswa memiliki mathematical habits of mind yang tinggi dalam dirinya.

Berdasarkan hasil signifikansi tersebut, sesuai dengan penelitian yang pernah dilakukan oleh Hanifah (2018) bahwa adanya hubungan yang signifikan antara kemampuan berpikir kritis matematis dengan habits of mind siswa dalam pembelajaran matematika. Menurut Bidari (2016), terdapat pengaruh yang signifikan antara habits of mind terhadap kemampuan generalisasi matematis siswa, dan menurut Qadarsih (2017) bahwa bahwa adanya pengaruh yang signifikan antara kebiasaan pikiran (habits of mind) terhadap penguasaan konsep matematika.

Kemudian, diperoleh koefisien determinasi sebesar 39,8\%, yang artinya peningkatan kemampuan literasi matematis siswa dipengaruhi oleh variabel mathematical habits of mind sebesar 39,8\% dan sisanya sebesar 60,2 \% dipengaruhi oleh faktor lain yang tidak diukur dalam penelitian ini.

Sesuai dengan penelitian yang pernah dilakukan sebelumnya oleh Qadarsih (2017) bahwa adanya pengaruh yang signifikan antara kebiasaan pikiran (habits of mind) terhadap penguasaan konsep matematika, dengan kontribusi kebiasaan pikiran (habits of mind) terhadap penguasaan konsep matematika sebesar 26,67 \%. Dan menurut Bidari (2016), terdapat pengaruh yang 
signifikan antara habits of mind terhadap kemampuan generalisasi matematis siswa, dengan besar pengaruhnya $42,5 \%$.

\section{SIMPULAN}

Berdasarakan hasil penelitian dan pembahasan, maka dapat disimpulkan bahwa terdapat hubungan yang signifikan antara mathematical habits of mind terhadap kemampuan literasi matematis siswa SMP di Kabupaten Bandung Barat, dengan pengaruh mathematical habits of mind terhadap kemampuan literasi matematis siswa sebesar 39,8\% dan sisanya dipengaruhi oleh faktor lain yang tidak diukur dalam penelitian ini. Memiliki mathematical habits of mind yang tinggi dalam diri siswa, akan memberikan peningkatan kemampuan literasi matematis yang baik.

\section{DAFTAR PUSTAKA}

Andriani, S., Yulianti, K., Ferdias, P., \& Fatonah, S. (2017). The effect of mathematical habits of mind learning strategy based on problem toward students' mathematical creative thinking disposition, $\operatorname{III}(9), 689-696$.

Bidari, I. (2016). Pengaruh habits of mind terhadap kemampuan generalisasi matematis siswa. Skripsi, tidak dipublikasikan. UIN Syarif Hidayatullah Jakarta.

Darma, Y., Firdaus, M., \& Haryadi, R. (2016). Hubungan kemandirian belajar terhadap kemampuan pemecahan masalah matematis mahasiswa calon guru matematika, 14(1), 10.

Ekawati, E. (2011). Peran, fungsi, tujuan, dan karakteristik matematika sekolah. Diambil dari http://p4tkmatematika.org/2011/10/peran-fungsi-tujuan-dan-karakteristik-matematikasekolah/

Hanifah, A. N., Mirna, Mulianty, H. R., \& Fitriani, N. (2018). Hubungan antara kemampuan berpikir kritis matematis dengan habits of mind siswa smk yang menggunakan pendekatan model eliciting activities (MEAs). Jurnal Pembelajaran Matematika Inovatif, 1(1), 49-56.

Hendriana, H., Rohaeti, E. E., \& Sumarmo, U. (2017). Habits of mind. Dalam Hard Skills dan Soft Skills Matematik Siswa (hlm. 146-147). Bandung: Refika Aditama.

Hutagalung, D. D. (2016). The correlation between self efficacy and motivation learning with mathematics learning outcomes students class xi ips sma negeri 5 batam academic year 2013/2014. Jurnal Mercumatika: Jurnal Penelitian Matematika dan Pendidikan Matematika, 1(1). https://doi.org/10.26486/mercumatika.v1i1.187

Miliyawati, B. (2014). Urgensi strategi disposition habits of mind, 3(2), 174-188.

OECD. (2017). How does PISA for development measure mathematical literacy? PISA for Development Brief, I(February 2014), 0-1. https://doi.org/10.1787/9789264208780-en

Peringkat dan Capaian PISA Indonesia Mengalami Peningkatan. (2016). Diambil dari https://www.kemdikbud.go.id/main/blog/2016/12/peringkat-dan-capaian-pisa-indonesiamengalami-peningkatan

Qadarsih, N. D. (2017). Pengaruh kebiasaan pikiran (habits of mind) terhadap penguasaan konsep matematika, 2(2), 5 .

Ruseffendi, E. T. (1980). Pengajaran matematika modern. Bandung: Tarsito.

Setiana, D. S. (2016). Komparasi penerapan metode pembelajaran ctl dan open-ended dengan memperhatikan gaya belajar ditinjau dari prestasi dan minat belajar matematika. Jurnal Mercumatika: Jurnal Penelitian Matematika dan Pendidikan Matematika, 1(1), 20. 
Sugiyono. (2011). Statistik nonparametrik untuk penelitian. Bandung: Alfabeta.

Zakiah, N. E. (2014). Pembelajaran dengan Pendekatan Open-Ended untuk Meningkatkan Kemampuan Metakognitif dan Mathematical Habits of Mind Siswa SMP. Tesis, tidak dipublikasikan. Universitas Pendidikan Indonesia. 